\title{
FACTORS THAT INFLUENCE THE EXTERNAL AUDITOR'S ASSESSMENT OF THE RISK OF FRAUD: AN AUDITOR'S PERCEPTION
}

\author{
Noviriliza Nadia Putri \\ noviriliza.nadia.putri@gmail.com, \\ Fakultas Ekonomi, Universitas Islam 45 \\ Hadi Mahmudah \\ hadimahmudah@gmail.com, \\ Fakultas Ekonomi, Universitas Islam 45 \\ Neneng Lasmita \\ Fakultas Ekonomi, Universitas Islam 45
}

\begin{abstract}
The purpose of this study was to see how factors such as professional skepticism, independence, client narcissism, and time constraints affect fraud risk assessments. This project obtained primary data by distributing questionnaires to the DKI Jakarta area auditors. We use web surveys to collect data. The population in this study amounted to 705 auditors. This investigation involved a total of 120 auditors. Hypothesis testing using SPSS software version 22 and multiple regression analysis. Based on the findings of this study, professional skepticism has a positive and significant effect on fraud risk assessment, independence, client narcissism has a positive and insignificant effect on fraud risk assessment, and time pressure has a negative and insignificant effect on fraud risk assessment. The implications of this study indicate that in assessing fraud risk, professional skepticism plays an important role, and auditors are required to build a high level of professional skepticism.
\end{abstract}

Keywords: professional skepticism, independence, client narcissism, time pressure, the auditor's fraud risk assessment.

\section{INTRODUCTION}

Fraudulent financial reporting has become a severe issue in recent years since it can result in financial and non-financial losses, such as the financial system and bankruptcy. According to a survey performed by Ernst \& Young (2013), 30\% of respondents feel their country's corporations have given fraudulent financial figures. For example, Global Enron, WorldCom, Tyco, and Symbol Technologies have taught us a lot about how to avoid financial fraud. As a result, firms must be more vigilant about corporate governance, while external auditors are expected to play a more prominent role in avoiding future fraud. According to a poll conducted by academics (Siregar \& Tenoyo, 2015), 88 percent of Indonesian employees agree that external auditors are a tool for detecting and preventing business fraud. Existing fraud cases and the findings of surveys suggest that fraud is still big enough to be observed by anyone with a significant role, mainly external auditors.

With the auditor's professional skepticism, the external auditor's fraud evaluation plays a critical function. The amount of professional skepticism of auditors is related to the expertise and character of each auditor. Because a suspicious mentality leads to more cautious audit conclusions, the auditor must cultivate his professional skepticism to mitigate the negative 
consequences of fraudulent financial reporting and serious misstatement in financial statements.

According to a study by (Endraningtyas \& Dewi, 2017), auditors' professional skepticism negatively impacts fraud risk assessment. Similarly, according to (Djatu Winardi et al., 2017), professional skepticism considerably impacts the external auditor's evaluation of fraud risk. Furthermore, (Rahmawati, 2016) research shows that auditors' professional skepticism has a favorable and significant impact on fraud risk assessment.

Internal variables such as Independence are thought to influence the external auditor's estimate of fraud risk. An auditor must be independent and retain professional objectivity in addition to displaying professional skepticism.(Endraningtyas \& Dewi, 2017) found that auditor independence has a positive but not statistically significant influence on fraud risk assessment. The research done by Fatimah and Suryanto, on the other hand, found that auditor independence improves their ability to detect fraud. Similarly, (Sulistyowati \& Supriyati, 2016) discovered that auditor independence improves fraud detection. This demonstrates that independent auditors can do their duties effectively; in other words, auditors cannot be swayed by third parties while making choices.

Client narcissism is a unique internal factor. Narcissism grows in a setting that rewards someone with narcissism with positive attention from others. Narcissism is a personality trait that can be linked to a fraud risk assessment. Because his character expects positive responses from others, a person with narcissism is more likely to engage in deviant behavior. The auditor may utilize red flags to identify potential fraud in financial reporting when analyzing fraud risk. When an audit is in progress, auditors frequently utilize red flags to uncover fraud and as a valuable signal; one example of a red flag is client narcissism. Client narcissism has a favorable and significant effect on the external auditor's estimate of fraud risk, according to a study by (Djatu Winardi et al., 2017). On the other hand, client narcissism has a favorable and insignificant effect on fraud risk assessment, according to (Endraningtyas \& Dewi, 2017) research.

Time constraint is another external issue that an auditor must consider when analyzing the risk of fraud. Auditors frequently work under time constraints; time pressure (steam pressure) is a common feature of the environment in which an auditor works when conducting an audit. This, combined with the grace period granted to the auditor at the end of the audit, creates a busy period for the auditor, which necessitates working quickly during the audit process. Time pressure has a negative influence on auditors' capacity to detect fraud, according to research conducted by (Anggriawan, 2014). Similarly,(Said \& Munandar, 2018) study shows that time constraint reduces auditors' capacity to detect fraud. The auditor's time pressure when conducting an audit can affect the audit's quality; the presence of high time pressure during the audit process can cause the auditor to improve efficiency in the audit process, resulting in the auditor's audit implementation not always be based on procedures and planning following applicable regulations. When completing the audit procedure, auditors are obligated to perform their tasks on schedule and within the time frame agreed upon between the auditor and the client.

\section{LITERATURE REVIEW AND HYPOTHESIS DEVELOPMENT}

Because this is an empirical study to establish the elements that influence fraud risk assessment, the theory of planned behavior (TPB) and the theory of job stress are used in this study.

\section{Client Narcissism is a type of narcissism that.}

In (Rahmawati, 2016), Morf \& Rhodewalt (2001) define narcissism as a personality type characterized by a sense of pride in oneself, a preference for self-interest, and a need for more attention. According to Morf \& Rhodewalt (2001) in (Rahmawati, 2016), Narcissists are 
preoccupied with fantasies of success, power, beauty, and brilliance. A narcissist's personality causes them to live in an interpersonal stage characterized by aberrant behavior, a need for attention, and admiration from others.

Narcissism is a personality trait that can be linked to a fraud risk assessment. Because his character expects positive responses from others, a person with narcissism is more likely to engage in deviant behavior. Auditors can employ fraudulent activity signals in the form of red flags to assess the risk of fraud. Red flags are events, conditions, situational pressures, opportunities, or personal characteristics that may cause management or employees to participate in fraud, according to Romney et al. (1980) in (Gullkvist \& Jokipii, 2013). This red flag is valuable to auditors since it can alert them to the possibility of fraud.

Auditors can employ other signs that arise specifically in certain settings (specific situational cues) to address existing fraud claims in addition to the regularly used red flags (Hammersley, 2011). The client's personality or other circumstances may provide these precise insights. If the signal from this event is combined with a red flag, the auditor's understanding of how the client commits fraud will be enhanced (Hammersley, 2011). According to (Johnson et al., 2013), one of these specific signs is a person's personality of narcissism, which can lead to dishonest financial reporting conduct.

\section{Formulation of Hypotheses \\ Professional Skepticism and Fraud Risk Assessment}

The Theory of Planned Behavior (TPB) can explain how skepticism affects auditors' ability to assess fraud risk. The determinant function of attitude toward conduct and subjective norms, according to (Respati, 2011), is a theory that underpins an auditor's skepticism. An auditor can retain a beneficial attitude when skepticism provides the correctness of the risk of fraud assessment.

Auditor scepticism has a favourable and significant effect on the risk assessment of fraud, according to (Endraningtyas \& Dewi, 2017) research. Because an auditor's professional scepticism is minimal, he or she will be unable to uncover fraud because the auditor just trusts the client's explanation without supporting proof. Meanwhile, the likelihood of fraud will be reduced if the auditor's professional skepticism is vital.

The researcher formulates the following hypothesis based on the existing theoretical foundation and to re-test the conflicting outcomes of earlier research:

H1: Professional scepticism influences audience assessment positively to the possibility of fraud from the outside

\section{The Relationship Between Fraud Risk Assessment and Independence}

The determinant function of attitude toward conduct and subjective norms, according to (Respati, 2011), is a hypothesis that underpins an auditor's Independence. The purpose of this determinant is to describe how an auditor's attitude of Independence ensures the correctness of the results of the risk assessment of fraud, allowing him to keep an attitude that benefits him.

According to a study conducted by (Yahya et al., 2021), Independence has a favorable and significant impact on fraud detection. Because the auditor has high integrity, he or she will not be bothered by intervention, threats, or pressure from other parties in detecting fraud. The stronger the auditor independence, the better the auditors' capacity to detect fraud.

The researcher formulates the following hypothesis based on the theoretical foundation and re-examine the conflicting outcomes of prior research:

$\mathrm{H} 2$ : The external auditor's evaluation of fraud risk is influenced by the auditor's independent attitude.

\section{Client Narcissism and Fraud Risk Assessment: Is There a Link?}

The Theory of Planned Behaviour (TPB) can explain how client narcissism affects auditors' ability to assess fraud risk. Because of his character, a person with narcissism prefers to act defiantly because he anticipates good responses from others (Paulhus and Williams, 2002 
in (Endraningtyas \& Dewi, 2017)). In terms of a narcissistic personality, (Hammersley, 2011) claims that fraud risk assessments that detect red flags such as motivation, opportunity, and rationalization will be enhanced when combined with particular clues to cheating from clients.

According to (Djatu Winardi et al., 2017), customer narcissism has a beneficial impact on the external auditor's risk of fraud assessment. Someone with a high level of narcissism will be more concerned with the final objective than with the process of obtaining that goal. As a result, the auditor should include client narcissism as a red signal to consider when assessing the risk of fraud because the higher the client's narcissism, the higher the external auditor's risk of fraud evaluation.

The researcher came up with the following hypothesis based on the theoretical foundation and past research:

H3: The external auditor's evaluation of fraud risk is influenced positively by the client's narcissism.

\section{Time Pressure and Fraud Risk Assessment: Is There a Link?}

When the audit time budget is misused, it can be harmful to the auditor. Auditors may feel pressured to complete specific audit tasks within a short time frame, which may encourage them to engage in dysfunctional conduct. This is based on the work stress hypothesis, which claims that (stress causes) can lead individuals to experience pressure (stress) while working, which can then impact individual attitudes and behaviour.

According to (Fatimah \& Suryanto, 2016)'s research, auditors' time constraints in searching for audit findings will diminish the audit's quality since auditors are compelled to finish their tasks on time. Thus they work quickly and are less thorough.

A specified time budget can encourage auditors to engage in quality-enhancing activities. Providing incentives and performance appraisals based on the amount of time budget achievement encourages auditors to make meeting the time budget a key priority while putting the audit program in place. When an auditor is faced with a high volume of work and a limited time budget, he or she is more likely to engage in audit quality reduction activities such as reducing sample size, skipping parts of the audit method, and accepting dubious client explanations.

The researcher generated the following hypothesis based on the theoretical foundation and to re-test the conflicting results of prior studies:

H4: The external auditor's estimate of the risk of fraud is influenced by time constraints.

\section{METHODS OF RESEARCH}

The methodologies used in this study are quantitative. The fraud risk assessment (Y) is the dependent variable, whereas professional skepticism (X1), Independence (X2), customer narcissism (X3), and time pressure are the independent factors (X4). This study's participants are auditors who work in the KAP DKI Jakarta area. The researcher chose auditors who work in Jakarta because there are many KAPs in Jakarta, and many are affiliated with international KAPs. The researcher used a web survey following the directions from Dilman 2014. The population was 705 , and the incoming questionnaires amounted to 130 , but only 120 had complete data. The questionnaires were distributed to $17 \mathrm{KAP}$ in DKI Jakarta, with a total of 120 completed questionnaires.

\section{Variable for Fraud Risk Assessment (Y)}

In (Djatu Winardi et al., 2017), Hall (2008) defines fraud as "the transmission of material facts wrongfully committed by one party to another party with the intent to deceive and induce others to rely on these facts." The fraud risk assessment variable instrument was created utilizing the following indicators, based on the fraud risk assessment concept described by (Keune et al., 2012).

\section{Profesional Skepticism is a variable (X1)}


Professional skepticism, according to (Noviyanti, 2008), is an attitude that involves a mind that is constantly questioning and doing critical evaluation as evidenced by an audit. The instrument used to measure the variable professional skepticism consisted of 17 previously used questions, which were administered in a questionnaire. The variable instrument of professional skepticism was developed using the following indicators: Questioning Mind, Suspension of Judgment, Search for Knowledge, Interpersonal Understanding, Self Confidence, and Self Determination, as well as Octavia's idea of professional skepticism.

\section{Variable of Independency}

According to (Mardijuwono \& Subianto, 2018), Independence demonstrates an impartial attitude and is not influenced by the pressures of certain parties while making judgments and taking actions. The instrument used to test the independence variable consisted of ten previously used items administered in the form of a questionnaire. The variable independence instrument was created utilizing the following indicators based on the idea of Independence presented by (Chiang, 2016): Independence in name only, Independence indeed, and Independence ineptitude.

\section{Variable for Client Narcissism}

According to (Campbell et al., 2005), Narcissism is an attitude that people hold to maintain and develop their high self-esteem. The case scenario is the tool employed to measure the variable. By producing (without being displayed) conversation signals from managers with high narcissism, the study involves talks between the auditor and the client manager (low narcissism).

The client's narcissism perception variable is measured using eight statements referring to cases and a scale of 1 to 4 to provide a scale of 1 to 4 . The larger the respondent's answer scale for Statements A, C, D, F, G, and H, the more narcissistic the client's behavior. While propositions $\mathrm{B}$ and $\mathrm{E}$ are negative statements, the lower the client's narcissism, the higher the respondent's answer scale. As a result, in judging statement B, E must be inverted. This study's instrument was created using instruments from Walidina's research (2013).

\section{Variable Time Pressure}

According to (Said \& Munandar, 2018), time pressure (time pressure) is a pressure on the audit time budget that has been created. There are two types of time pressure: time budget pressure and time deadline pressure. The necessity to perform audit work according to a specific time limit causes time deadline pressure, whereas the amount of time assigned to completing specific audit tasks causes time budget pressure.

Validity and reliability were assessed before the regression analysis. The results of the Pearson moment validity test show that all of the questionnaire's items are valid. Then do the reliability test, which should yield the following results:

Tabel 1: Instrument reliability test result

\begin{tabular}{lll} 
Variable & Cronbach's Alpha & Keterangan \\
\hline Assesment risk of fraud & .747 & $\begin{array}{l}\text { Reliab } \\
\text { le }\end{array}$ \\
\hline Professional scepticism & .829 & Reliable \\
\hline Independence & .772 & $\begin{array}{l}\text { Reliab } \\
\text { le }\end{array}$ \\
\hline Client narcissism & .726 & Reliable \\
\hline Time pressure & .870 & Reliable \\
\hline
\end{tabular}

\section{Results of the Determination Coefficient Test (R2)}

This test is used to determine the ability of the independent variables, namely professional skepticism, Independence, customer narcissism, and time pressure, to explain the 
variation in the dependent variable, namely the risk of fraud assessment. The results of the coefficient of determination test are displayed in the modified R square column of the table 2:

Tabel 2: Result of correlation test and cooficient of determination

\section{Model Summary}

\begin{tabular}{lllll}
\hline Model & $\mathrm{R}$ & R Square & $\begin{array}{l}\text { Adjusted } \\
\text { Square }\end{array}$ & $\begin{array}{c}\text { R Std. An error of } \\
\text { the Estimate }\end{array}$ \\
\hline 1 & $.412^{\mathrm{a}}$ & .170 & .141 & .088 \\
\hline
\end{tabular}

The adjusted $\mathrm{R}$ square of 0.141 or 14.1 percent is shown in the table above. As a result, the variable fraud risk assessment $(\mathrm{Y})$ is 14.1 percent, which may be explained by the variables professional skepticism (X1), Independence (X2), customer narcissism (X3), and time pressure (X4). Other variables not included in the regression model account for the remaining $85.9 \%$ of the variance.

The correlation coefficient $\mathrm{R}$ in the table is 0.412 , or 41.2 percent, suggesting a high correlation between the independent and dependent variables because it is more than 0.050. The SEE (Standard Error of Estimation) is 3,379. The regression model will be more precise in predicting the dependent variable if the SEE value is lower.

\section{Results of the F Test (Model Feasibility)}

Simultaneous significance testing ( $F$ test) is used to determine whether all of the independent variables in a regression model have a significant effect on the dependent variable at the same time. The findings are shown in the table 3 :

Tabel 3: $F$ test result

\begin{tabular}{|c|c|c|c|c|c|c|}
\hline \multicolumn{7}{|c|}{ ANOVA $^{b}$} \\
\hline Model & & $\begin{array}{l}\text { Sum o } \\
\text { Squares }\end{array}$ & Df & $\begin{array}{l}\text { Mean } \\
\text { Square }\end{array}$ & $\mathrm{F}$ & Sig. \\
\hline \multirow[t]{3}{*}{1} & Regression & .183 & 4 & .046 & 5.868 & $.000^{\mathrm{b}}$ \\
\hline & Residual & .897 & 115 & .008 & & \\
\hline & Total & 1.080 & 119 & & & \\
\hline
\end{tabular}

The estimated F test of 5.868 is greater than the $\mathrm{F}$ table 2.45 (5.868> 2.45), according to the data processing results in the table above. The results of the hypothesis testing reveal that professional skepticism, Independence, client narcissism, and time constraint all impact the risk assessment of fraud.

\section{Result of the T-test (partial)}

The partial regression test (t-test) is helpful in determining the effect of each independent variable on the dependent variable. By comparing the probability value of each independent variable with a significance threshold of 0.050 , you can see whether or not each independent variable affects the dependent variable. When the significant result is less than 0.050 , the independent variables are said to partially affect the dependent variable. The partial regression test ( $\mathrm{t}$-test) results are shown in the table below:

Tabel 4: t-test result

\section{Coefficients}

\begin{tabular}{lllll} 
& & Standardize & \\
& Unstandardiz & $\mathrm{d}$ & & \\
Model & ed & Coefficient & & \\
Coefficients & $\mathrm{s}$ & $\mathrm{t}$ & Sig. \\
\hline
\end{tabular}




\begin{tabular}{lllllll}
\hline & & \multicolumn{5}{l}{ Std. } \\
& $\mathrm{B}$ & Error & Beta & & \\
\hline 1 (Constant) & 1.044 & .566 & & 1.843 & .068 \\
& $\begin{array}{l}\text { Professional } \\
\text { skepticisim }\end{array}$ & .295 & .096 & .267 & 3.084 & .003 \\
& & & & & \\
Independence & .302 & .099 & .263 & 3.052 & .003 \\
& Client narsism & .080 & .101 & .068 & .794 & .429 \\
& Time pressure & -.015 & .035 & -.36 & -.421 & .675 \\
\hline
\end{tabular}

\section{DISCUSSION}

\section{The Initial Hypothesis Test (H1)}

The study's findings reveal that the first hypothesis of professional skepticism has a favorable and significant impact on fraud risk assessment. Hence H1 is accepted. When the auditor assesses the risk of fraud, professional skepticism is an internal factor since professional skepticism is the auditor's mindset, which includes querying and critically examining audit data. A skeptical auditor will not just accept the client's answer; instead, he or she will interrogate the client in order to gather reasoning, proof, and confirmation about the object in question.

Auditors will only detect misstatements caused by errors if they do not utilize professional skepticism, and it is challenging to find misstatements created by fraud because offenders frequently disguise fraud. As a result, if the auditor lacks professional skepticism, he or she may be unable to spot fraud. Apart from being financially damaging to the public accounting business, this mistake also resulted in the public accountant's reputation being tarnished and creditors and investors losing faith in the capital market.

The findings of this study back up that of (Endraningtyas \& Dewi, 2017), who found that professional skepticism had a favorable and significant impact on fraud risk assessment.

\section{Testing a second hypothesis (H2)}

According to the findings, the second hypothesis of Independence has a favorable and significant impact on fraud risk assessment. It is safe to say that $\mathrm{H} 2$ is acceptable. Because Independence is a mental attitude that is free of influence, is not governed by others, and is not reliant on others, it may be argued that Independence is the auditor's honesty in examining facts with no objective factors. When forming and expressing an opinion, the auditor should take sides. During the audit process, public accountants earn the trust of clients and financial statement consumers by demonstrating the accuracy of financial reports created and presented by clients. As a result, when expressing a judgment on the fairness of the audited financial accounts, the auditor must act independently of the client's, users', and the public accountant's interests.

An auditor is not regarded as independent if he or she has personal ties to the auditee (for example, family ties or financial ties) that could raise doubts about the auditor's impartiality. As a result, auditors must operate freely in accordance with the facts and avoid situations that cause others to question their Independence.

The findings of this study back up the findings of (Agustina, 2021), who found that Independence has a beneficial impact on fraud risk assessment.

\section{Testing a third hypothesis $(\mathrm{H3})$}

According to the findings, the third hypothesis of customer narcissism has a favorable but minor effect on fraud risk assessment. H3 is not going to work. Because the auditor cannot conclude that if the client has narcissistic tendencies, the client's business has a high risk of 
fraud, because the client's perspective of narcissism is difficult to perceive, the client's view of narcissism does not have a direct effect on the risk assessment of fraud.

The findings of this study back up the findings of (Endraningtyas \& Dewi, 2017), who found that client narcissism had a favorable but minor impact on fraud risk assessment.

\section{Fourth, test your hypotheses (H4)}

The findings suggest that the fourth hypothesis, time pressure, has a detrimental impact on the risk assessment of fraud; hence, $\mathrm{H} 4$ is rejected. Based on these findings, it may be inferred that time constraint reduces an auditor's sensitivity to misstatement since the auditor focuses solely on the work at hand, causing the auditor to miss fraud. Auditors will have a busy season to finish their jobs on time due to time constraints. On the other hand, auditors tend to work carelessly and may overlook minor details that lower the level of confidence and accuracy in financial accounts. Even the presence of time pressure will impact auditors' failure to discover fraud due to inaccuracy of fraud symptoms or indications.

The findings of this study back up (Fatimah \& Suryanto, 2016) research, which found that time budget pressure has a negative and minor impact on fraud risk assessment.

\section{CONCLUSION}

The purpose of this study is to look at the factors that influence an external auditor's fraud risk assessment. Respondents in this survey included 120 auditors from the Jakarta Public Accounting Firm (KAP), a member of the Indonesian Institute of Certified Public Accountants (IAPI). Based on the information gathered and the results of the testing performed with the SPSS 22 software, the following conclusions can be drawn: Independence has a positive and substantial effect on fraud risk assessment, but professional skepticism has a positive and significant effect on fraud risk assessment. Client narcissism has a non-significant positive and favorable effect on a fraud risk assessment. Time restrictions have a negative and modest impact on the risk assessment of fraud.

Due to some constraints, this study was done. As a result, it is envisaged that future research will be able to reduce the current limits. The following are some of the study's limitations:

1. Because this study was limited to auditors working in public accounting offices in DKI Jakarta, the findings and conclusions cannot be applied to other external auditors in Indonesia.

2. Research conducted by a questionnaire survey method, which is prone to bias.

3. In this study, the variables that influence the fraud risk assessment process are professional skepticism, Independence, client narcissism, and time constraint.

4. Because the questionnaire distribution coincided with the busy season for auditors (peak season), many public accounting firms refused to take questionnaires to fill out, resulting in less-than-optimal data gathering. As a result, the findings of this study do not support the third hypothesis, according to which client narcissism has a beneficial impact on fraud risk assessment.

The following are some suggestions for improving future research that can be made in light of the study's numerous limitations: The scope of respondents has been broadened to include auditors in the DKI Jakarta area and public accounting businesses throughout Indonesia. It is envisaged that future studies will combine research with the interview method with auditors. The researcher wants the next researcher participant to identify new elements that affect fraud risk assessment by auditors by expanding the variables that affect fraud risk assessment. To give more relevant and accurate data, the next researcher is likely to boost the number of respondents with more than five years of job experience. Further research is expected to be conducted outside of the peak auditor season, such as July to September, to acquire more relevant data. 


\section{REFERENCY}

Agustina, F. (2021). Research in Business \& Social Science Auditors 'professional skepticism and fraud detection. 10(4), 275-287.

Anggriawan, E. F. (2014). Pengaruh pengalaman kerja, skeptisisme profesional, dan tekanan waktu terhadap kemampuan mendeteksi fraud. Jurnal Nominal, 3(2), 30-36.

Campbell, W. K., Bush, C. P., Brunell, A. B., \& Shelton, J. (2005). Understanding the social costs of narcissism: The case of the tragedy of the commons. Personality and Social Psychology Bulletin, 31(10), 1358-1368. https://doi.org/10.1177/0146167205274855

Chiang, C. (2016). Conceptualising the linkage between professional scepticism and auditor independence. Pacific Accounting Review, 28(2), 180-200. https://doi.org/10.1108/PAR08-2015-0034

Djatu Winardi, R., Mustikarini, A., \& Permana, Y. (2017). Do Auditor Professional Scepticism and Client Narcissism Affect Fraud Risk Assessment? The Indonesian Journal of Accounting Research, 20(1), 71-98. https://doi.org/10.33312/ijar.347

Endraningtyas, R., \& Dewi, herlina R. (2017). Faktor-faktor yang mempengaruhi penilaian auditor eksternal atas risiko kecurangan. 17(2), 120-131.

Fatimah, I., \& Suryanto, R. (2016). Pengaruh Pengalaman Aauidtor, Indepenensi, Tekanan Waktu, dan Skeptisisme Profesional Auditor Terhadap kemampuan Auditor dalam Mendeteksi Kecurangan (Fraud). In thesis.

Gullkvist, B., \& Jokipii, A. (2013). Critical Perspectives on Accounting Perceived importance of red flags across fraud types. 24, 2012-2014. https://doi.org/10.1016/j.cpa.2012.01.004

Hammersley, J. S. (2011). A Review and Model of Auditor Judgments in Fraud-Related Planning Tasks. Auditing: A Journal of Practice \& Theory, 30(4), 101-128. https://doi.org/10.2308/ajpt-10145

Johnson, E. N., Kuhn, J. R., Apostolou, B. A., \& Hassell, J. M. (2013). Auditor perceptions of client narcissism as a fraud attitude risk factor. Auditing, 32(1), 203-219. https://doi.org/10.2308/ajpt-50329

Keune, M. B., Johnstone, K. M., Keune, M. B., \& Johnstone, K. M. (2012). Materiality Judgments and the Resolution of Detected Misstatements: The Role of Managers , Auditors, and Audit Committees. The Accounting Review, 87(5), 1641-1677. https://doi.org/10.2308/accr-50185

Mardijuwono, A. W., \& Subianto, C. (2018). Independence, professionalism, professional skepticism. Asian Journal of Accounting Research, 3(1), 61-71. https://doi.org/10.1108/ajar-06-2018-0009

Noviyanti, S. (2008). S K E P T I S M E P R O F E S IO N A L A U D I T O R D A L A M M E N D E T E K S I K E C U R A N G A N Suzy N oviyanti. Jumal Akuntansi Dan Keuangan Indonesia, 5(1), 102-125.

Rahmawati, D. (2016). Pengaruh Skeptisisme Profesional, Integritas, beban kerja dan persepsi narsisme terhadap penilaian risiko kecurangan (studi empiris pada KAP di Daerah Yogyakarta dan Jawa tengah. Repisitory UMY.

Respati, N. wening T. (2011). Pengaruh locus of control terhadap hubungan sikap manajer, norma-norma subyektif, kendali perilaku persepsian, dan intensi manajer dalam melakukan kecurangan penyajian laporan keuangan. Jurnal Akuntansi Dan Keuangan Indonesia, 8(2), 123-140.

Said, L. L., \& Munandar, A. (2018). the Influence of Auditor'S Professional Skepticism and Competence on Fraud Detection: the Role of Time Budget Pressure. Jurnal Akuntansi Dan Keuangan Indonesia, 15(1), 104-120. https://doi.org/10.21002/jaki.2018.06

Siregar, S. V., \& Tenoyo, B. (2015). Journal of Financial Crime Fraud awareness survey of private sector in Indonesia Fraud awareness survey of private sector in Indonesia. Journal 
of Financial Crime Managerial Auditing Journal Journal of Financial Crime Iss Journal of Financial Crime Journal of Financial Crime Journal of Financial Crime, 222222(1), 329-346.

http://dx.doi.org/10.1108/JFC-03-20140016\%5Cnhttp://dx.doi.org/10.1108/JFC-07-2013-0045

Sulistyowati, L., \& Supriyati, S. (2016). The effect of experience, competence, independence, and professionalism of auditors on fraud detection. The Indonesian Accounting Review, 5(1), 95. https://doi.org/10.14414/tiar.v5i1.494

Yahya, febrina, Yustina, A. I., \& Mahmudah, H. (2021). The Mediating Role of Independence in the Relationship between Auditors' Conscientiousness \& Openness and Professional Skepticism. Jurnal Pengurusan, 61. 